\title{
Gold in central West Greenland - known and prospective occurrences
}

\author{
Agnete Steenfelt, Henrik Stendal, Bo Møller Nielsen and Thorkild M. Rasmussen
}

In 2003, the Geological Survey of Denmark and Greenland (GEUS) completed a four-year project aimed at assessing the mineral potential of the Precambrian region of West Greenland between latitudes $66^{\circ}$ and $70^{\circ} 15^{\prime} \mathrm{N}$. The project was part of a contract between GEUS and the Ministry of the Environment, and involved compilation of existing geoscientific data, new geological mapping, field examinations of known and potential mineral occurrences, new chemical and isotope analyses, and data interpretation. The data compilation, available on a DVD (Schjøth et al. 2004), comprises regional, systematically acquired data sets presented in a Geographic Information System environment. Aeromagnetic, aeroradiometric, stream sediment and rock geochemical and gravity data, a digital elevation model and a satellite image are included, plus descriptions of 60 mineral occurrences. Evaluation of the mineral potential is based on interpretations of the compiled information as well as on earlier investigations by the Survey, the University of Copenhagen and commercial companies (see e.g. Stendal \& Schønwandt 2003; Stendal et al. 2004).

From an economic point of view, the potential for gold and diamonds is the most interesting in the investigated area. This paper summarises the evaluation of the gold potential; results of diamond-related investigations are reported separately (Jensen \& Secher 2004, this volume).

\section{Geological setting}

While the Ataa and Nassuttooq areas (Fig. 1) were comparatively well known before the onset of the project, only limited information was available on large parts of the intervening tract. Important aspects of the present project have therefore included establishment of the geological relationships between the northern and southern areas, as well as the ages and plate-tectonic settings of lithological units and their mineralisation.

An overview of the geology of the area is presented in Fig. 1. Geological descriptions and further references may be found in Garde \& Steenfelt (1999) and van Gool et al. (2001). Granitoid orthogneisses of Archaean age with subordinate supracrustal sequences underlie almost the entire area. Radiometric age determinations and structural studies have

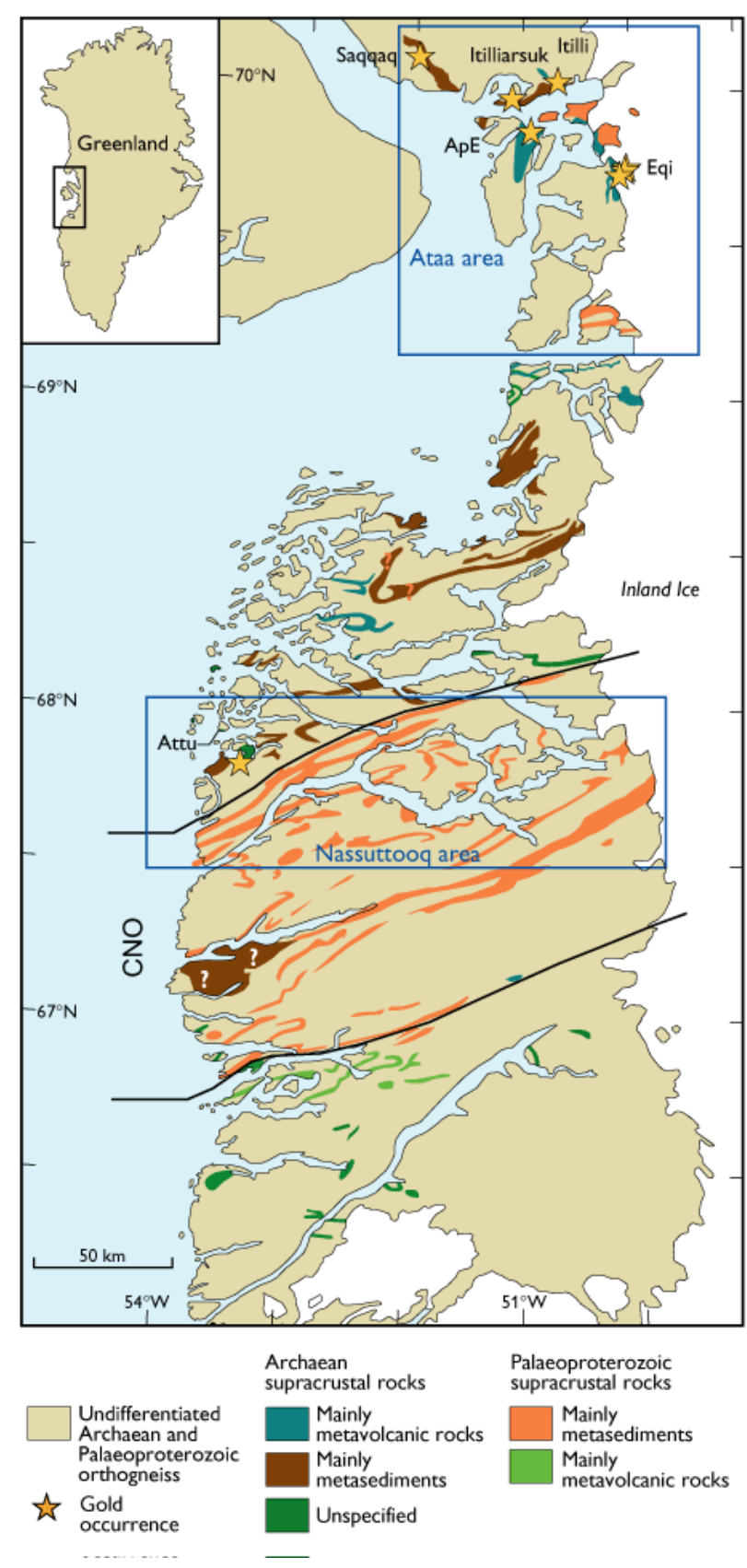

Fig. 1. Map of central West Greenland showing supracrustal rocks and known gold occurrences. Isotopic data suggest that some supracrustal sequences comprise both Archaean and Palaeoproterozoic rocks (question marks). CNO, central Nagssugtoqidian orogen; ApE, Arveprinsen Ejland. Modified from van Gool et al. (2002). 
documented that some of the supracrustal sequences are Archaean while others are Palaeoproterozoic in age.

Most of the Archaean crust in the study region was formed around $2.8 \mathrm{Ga}$, probably by accretion of tonalitic magmatic complexes formed at constructive continental margins. However, remnants of older continents have also been recognised, such as enclaves of mid-Archaean (c. $3 \mathrm{Ga}$ ) rock complexes and a small occurrence of early Archaean orthogneiss $(3.6 \mathrm{Ga})$ in the south-eastern corner of the region. The metavolcanic sequences in the Ataa area were probably formed in a volcanic arc setting, while supracrustal sequences elsewhere are dominated by sediments and are likely to represent continental rift or margin settings. Late Archaean (c. $2.75 \mathrm{Ga}$ ) crustal heating with formation of pegmatites and granite veins has affected the entire region.

The Archaean basement together with Palaeoproterozoic cover rocks has been variably affected by the Palaeoproterozoic Nagssugtoqidian orogeny that lasted from c. 2.0 to 1.75 $\mathrm{Ga}$. The orogeny involved initial continental rifting accompanied by intrusion of a dolerite dyke swarm, a subduction phase with extrusion and intrusion of quartz dioritic and monzodioritic magmas, and a final continental collision phase around $1.84 \mathrm{Ga}$ resulting in folding, thrusting, shearing, metamorphism and local melting. At the same time as post-kinematic pegmatites and granites were emplaced at $c$. $1.8 \mathrm{Ga}$ north of the central Nagssugtoqidian domain, ultramafic lamprophyres were intruded in the Ataa area. Much later, the southern continent of the Nagssugtoqidian orogen was the focus of recurrent alkaline and carbonatitic magmatism (Larsen \& Rex 1992) resulting in numerous lamprophyre and carbonatitic dykes (see Jensen \& Secher 2004, this volume) in addition to the major Sarfartoq carbonatite complex (c. 0.6 Ga).

\section{Known gold occurrences}

Eight mineral occurrences with prospective gold concentrations (i.e. above one gramme per ton, 1 ppm) have been identified during commercial and government exploration in the study region, although none have so far proved economic in size and grade (Fig. 1; Stendal 1998; Stendal et al. 2002; Stendal \& Schønwandt 2003). The known auriferous mineral occurrences are all hosted in Archaean rocks. Two are stratabound and were probably formed during deposition of the host sediments and lavas, while the others are located in cross-cutting veins, alteration zones, breccias and shear zones.

Itilli. The oldest known metavolcanic rocks in the region are the amphibolites at Itilli, which are intruded by a 3 Ga old quartz diorite (Thrane \& Connelly 2002). The setting is possibly a volcanic arc. Disseminated sulphides within the amphibolites are closely related to short, variably oriented shear zones. Locally these shear zones host quartz lenses (5-10 $\mathrm{cm}$ wide and $1 \mathrm{~m}$ long) parallel to the fabric of the shear zone, that are often surrounded by a halo of hydrothermal alteration. Veinlets and disseminated sulphides including chalcopyrite occur both in the quartz lenses and the sheared amphibolite and contain $0.7 \mathrm{ppm} \mathrm{Au}$. Other shear zones along a thrust contact between amphibolites and metasediments, up to $25 \mathrm{~cm}$ wide, contain quartz lenses and nickelarsenides (e.g. gersdorffite). Analyses of chip samples from these shear zones have yielded values of up to $0.3 \% \mathrm{Cu}, 1.3$ ppm Au and $1.5 \% \mathrm{Ni}$.

Saqqaq. The supracrustals comprise felsic metasedimentary rocks with subordinate mafic and ultramafic metavolcanic units. The sequence may represent deposition in a continental rift or at an active continental margin. The age is not known, but believed to be Archaean. Gold occurs in a 1 to $2 \mathrm{~m}$ thick garnet-quartz horizon situated at the boundary between ultramafic lavas and mica schist. The horizon has been interpreted as a syngenetic exhalative chert (Garde et al. 1999), or alternatively a silicified shear zone (NunaMinerals 2000). The auriferous metachert layer contains a few per cent of disseminated sulphides. Gold values are in the range of 1-16 ppm over 1-2 $\mathrm{m}$, and the auriferous bed can be followed for at least $4 \mathrm{~km}$. In addition to gold, the mineralised layer also has high concentrations of As (average $404 \mathrm{ppm}$ ), $\mathrm{Ni}$ (average $652 \mathrm{ppm}$ ) and $\mathrm{Cr}$ (average $1403 \mathrm{ppm}$ ).

Eqi. The metamorphosed mafic and felsic volcanic rocks are considered part of a $2.8 \mathrm{Ga}$ old volcanic island arc. Three types of gold mineralisation are found. Syngenetic gold occurs in up to $20 \mathrm{~cm}$ thick lenses of semi-massive pyrite situated in a 50-200 m wide zone between rhyolitic lava and sericite-rich sediment. Composite grab samples of massive pyrite have yielded up to $0.2 \% \mathrm{Cu}$ and $1 \mathrm{ppm} \mathrm{Au}$. Hydrothermal activity associated with the volcanism at Eqi resulted in pervasive carbonate alteration along $\mathrm{N}-\mathrm{S}$-trending zones. The carbonatised rocks consist of ankerite, chlorite, green fuchsitic mica and disseminated pyrite. Chip samples of carbonate alteration have given up to $2.3 \mathrm{ppm} \mathrm{Au}$ over $2.5 \mathrm{~m}$, while grab samples of quartz-veined rocks have yielded between $5 \mathrm{ppb}$ (microgramme per ton) and $60 \mathrm{ppm}$ $\mathrm{Au}$. The third kind of gold mineralisation is hosted by a $10 \mathrm{~m}$ wide and $100 \mathrm{~m}$ long breccia zone, is clearly epigenetic and is Palaeoproterozoic in age. The breccia is situated immediately west of a major $\mathrm{N}-\mathrm{S}$-trending thrust separating the greenschist facies volcanic rocks to the east from amphibolite facies sedimentary rocks to the west. The breccia includes pyrrhotite, pyrite and chalcopyrite, and minor amounts of sphalerite and arsenopyrite. The main zone yielded up to $1.7 \mathrm{ppm}$ Au over $1 \mathrm{~m}$, and the best section of 12 short drill holes assayed $1.3 \% \mathrm{Cu}$ and $12 \mathrm{ppm}$ Au over $3.2 \mathrm{~m}$. 
Arveprinsen Ejland. The supracrustal sequence (Fig. 1, ApE) probably forms part of the same volcanic island arc represented at Eqi. It comprises mafic metavolcanic lavas and a mafic sill complex. Disseminated pyrrhotite and pyrite are common and semi-massive to massive lenses of sulphide also occur. Quartz veins with up to $2.6 \mathrm{ppm}$ Au occur in minor pyrite-rich shear zones. Samples of hydrothermally altered sulphide within a fault zone have assayed between 8 and 25 ppm Au. $\mathrm{Pb}-\mathrm{Pb}$ isotope data indicate that the hydrothermal alteration is Palaeoproterozoic in age.

Itilliarsuk. The metasediment-dominated supracrustal sequence along the south coast of Nuussuaq hosts large, rusty-weathering iron-formations in the form of both magnetite-rich bands and semi-massive sulphide. Mica schist with disseminated pyrrhotite and pyrite attains a thickness of about $150 \mathrm{~m}$. NunaMinerals (2000) have identified several sites with epigenetic gold mineralisation in sulphide-rich schists, quartz veins and shear zones. The best target is a shear zone that hosts a quartz-sericite rock yielding $9 \mathrm{ppm}$ of $\mathrm{Au}$ over $1.7 \mathrm{~m}$. The mineralised structure can be traced $500 \mathrm{~m}$ along strike.

Attu. This gold occurrence is the only place outside the Ataa area where gold concentrations above 1 ppm have so far been recorded. A prominent mylonite zone comprising pegmatite veining, silicification, magnetite and sulphide mineralisation cuts through granulite facies orthogneiss. The zone is $100-330 \mathrm{~m}$ wide, strikes $75^{\circ}$ and dips $60-70^{\circ} \mathrm{W}$. Samples of silicified mylonite assayed 2 to $8 \mathrm{ppm} \mathrm{Au}$.

\section{Favourable areas for further gold prospecting}

The distribution and ages of known gold occurrences within the study region demonstrate that gold-bearing mineralising systems have been active at various times throughout the geological evolution of the study region. Syngenetic gold mineralisation is evident in Archaean times where the favourable environments appear to have been rift or active continental margin and volcanic island arcs. Renewed heating and associated hydrothermal circulation in these environments could remobilise and deposit gold where fluids moving along shear zones and faults pass through basic, reducing rocks at the appropriate temperature. Several events are known, which may have triggered epigenetic gold mineralisation: $c .2 .75 \mathrm{Ga}$ granite intrusions, Palaeoproterozoic (c. 1.9 Ga?) intrusion of sills in the Ataa area, c. 1.84 Ga deformation and heating resulting from continent collision, 1.8 to $1.7 \mathrm{Ga}$ granite and pegmatite veining, c. $1.75 \mathrm{Ga}$ lamprophyre intrusion, and albitisation in the Ataa area, possibly younger than $1.7 \mathrm{Ga}$.

Figure 2 shows favourable areas for gold mineralisation based on the following criteria: (1) presence of stream sed-

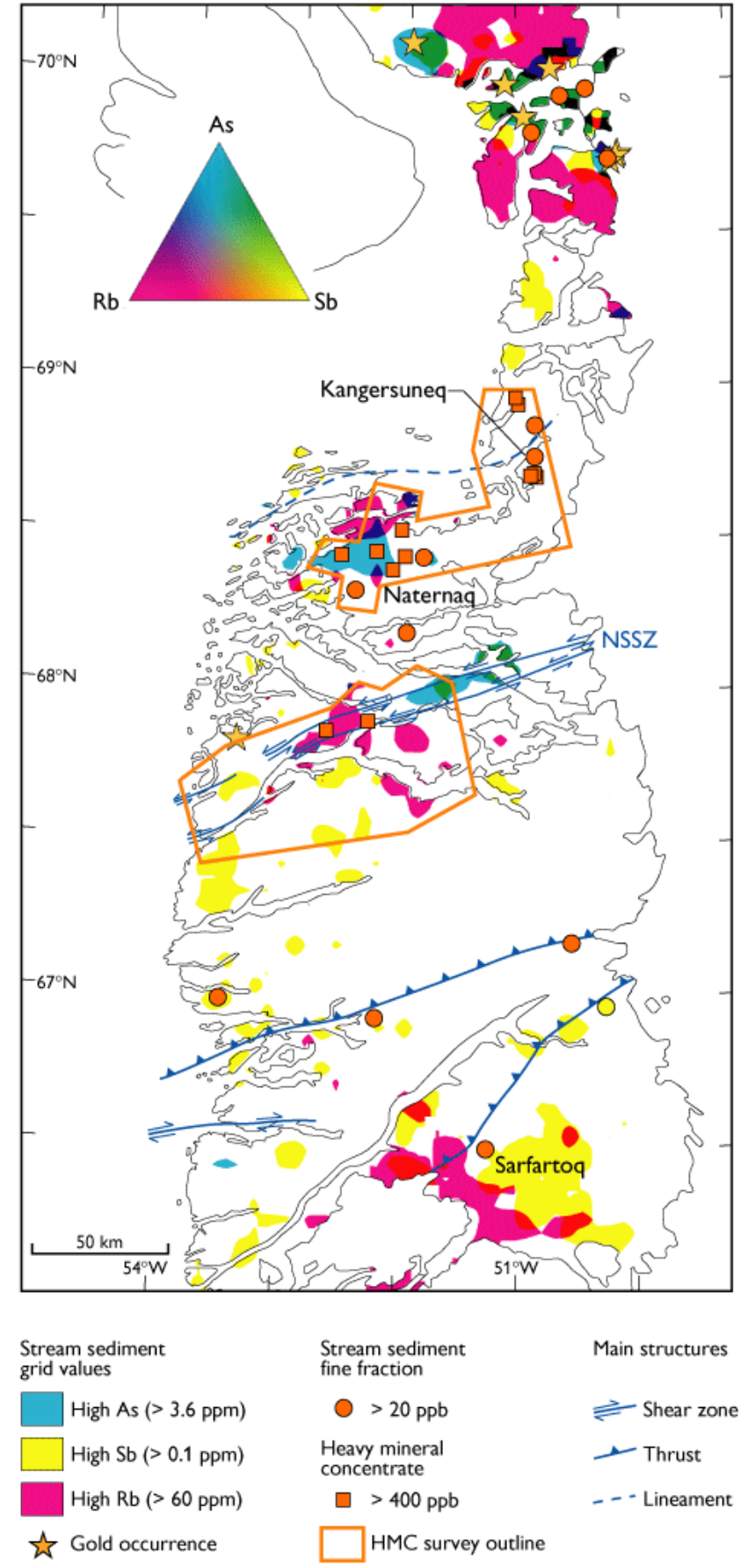

Fig. 2. Gold anomalies and gold prospective areas in central West Greenland. Stream sediment collected over the entire region at a spacing of 4 to $6 \mathrm{~km}$ by GEUS (Steenfelt 2001). Heavy mineral concentrates of stream sediment (HMC) collected in selected areas by Nunaoil A/S (Sieborg 1992). HMC and < $0.1 \mathrm{~mm}$ grain size fraction of stream sediment types analysed by the instrumental neutron activation method. The distribution of high concentrations of $\mathrm{As}, \mathrm{Sb}$ and $\mathrm{Rb}$ is illustrated by combined contoured grids. Gridding was carried out with a cell size of $5 \mathrm{~km}$ using a Kriging method. The triangle shows range of colours where grids overlap. NSSZ, Nordre Strømfjord shear zone. 
ments with high gold contents in the fine fraction or in heavy mineral concentrates; (2) areas where high arsenic (As), antimony $(\mathrm{Sb})$ and rubidium $(\mathrm{Rb})$ in stream sediment data coincide. As and $\mathrm{Sb}$ are frequently mobilised and precipitated together with $\mathrm{Au}$ in nature, and high $\mathrm{Rb}$ reflects the distribution of granitic magmatism; (3) areas in the vicinity of major faulting, shearing and thrusting; (4) presence of supracrustal rocks (see Fig. 1), particularly basic and reducing lithologies.

Apart from the Ataa area where conditions are very favourable (Fig. 1), the area around Naternaq seems the most prospective. Gold values of $c .2 \mathrm{ppm}$ have been reported, but such concentrations have not been reproduced in samples collected during the present project. The same is the case regarding the cluster of anomalies near Kangersuneq. Later prospecting and sampling by NunaMinerals and GEUS have been unable to explain or reproduce the anomalies. Other environments of interest for further prospecting are the Nordre Strømfjord shear zone (NSSZ), and the vicinity of major thrust zones in the southern study region (Fig. 2).

\section{References}

Garde, A.A. \& Steenfelt, A. 1999: Precambrian geology of Nuussuaq and the area north-east of Disko Bugt, West Greenland. Geology of Greenland Survey Bulletin 181, 7-40.

Garde, A.A., Thomassen, B., Tukiainen, T. \& Steenfelt, A. 1999: A goldbearing volcanogenic-exhalative horizon in the Archaean(?) Saqqaq supracrustal rocks, Nuussuaq, West Greenland. Geology of Greenland Survey Bulletin 181, 119-128.

Jensen, S.M. \& Secher, K. 2004: Investigating the diamond potential of southern West Greenland. Geological Survey of Denmark and Greenland Bulletin 4, 69-72 (this volume).

Larsen, L.M. \& Rex, D.C. 1992: A review of the 2500 Ma span of alkalineultramafic, potassic and carbonatitic magmatism in West Greenland. Lithos 28, 367-402.

NunaMinerals 2000: An overview of the Company and its prospects, 8 pp. Unpublished report, NunaMinerals A/S, Nuuk.
Schjøth, F., \& Steenfelt, A., (eds) 2004: Mineral resources of the Precambrian shield of central West Greenland ( $66^{\circ}$ to $\left.70^{\circ} 15^{\prime} \mathrm{N}\right)$. Part 1. Compilation of geoscience data. Danmarks og Grønlands Geologiske Undersøgelse Rapport 2004/16, 45 pp.

Sieborg B. 1992: Geochemical exploration in West Greenland. July-August 1991, Vol. 1, 36 pp., 6 app. Vol. 2, 28 plates. Unpublished report, Nunaoil A/S, Copenhagen, Denmark (in archives of Geological Survey of Denmark and Greenland, GEUS Report File 21080).

Steenfelt, A. 2001: Geochemical atlas of Greenland - West and South Greenland. Danmarks og Grønlands Geologiske Undersøgelse Rapport 2001/46, 39 pp. + 1 CD-ROM.

Stendal, H. 1998: Contrasting Pb isotopes of Archaean and Palaeo-proterozoic sulphide mineralisation, Disko Bugt, central West Greenland. Mineralium Deposita 33, 255-265.

Stendal, H. \& Schønwandt, H.K. 2003: Precambrian supracrustal rocks and mineral occurrences, Northeast Disko Bugt. Danmarks og Grønlands Geologiske Undersøgelse Rapport 2003/24, 57 pp.

Stendal, H., Blomsterberg, J., Jensen, S.M., Lind, M., Madsen, H.B., Nielsen, B.M., Thorning, L. \& Østergaard, C. 2002: The mineral resource potential of the Nordre Strømfjord - Qasigiannguit region, southern and central West Greenland. Geology of Greenland Survey Bulletin 191, 39-47.

Stendal, H., Nielsen, B.M., Secher, K. \& Steenfelt, A. 2004: Mineral resources of the Precambrian shield of central West Greenland $\left(66^{\circ}\right.$ to $70^{\circ} 15^{\prime}$ N). Part 2. Mineral resources. Danmarks og Grønlands Geologiske Undersøgelse Rapport 2004/20, 212 pp.

Thrane, K. \& Connelly, J. 2002: Linking the Nagssugtoqidian orogen and the Rinkian belt: preliminary ages from the Disko Bugt region. In: Nielsen, B.M. \& Thrane, K. (eds): Workshop on Nagssugtoqidian and Rinkian geology, West Greenland. Danmarks og Grønlands Geologiske Undersøgelse Rapport 2002/9, 46-48.

van Gool, J.A.M., Connelly, J.N., Marker, M. \& Mengel, F. 2001: The Nagssugtoqidian Orogen of West Greenland: tectonic evolution and regional correlations from a West Greenland perspective. Canadian Journal of Earth Sciences 39, 665-686.

van Gool, J.A.M., Alsop, I., Árting, U.E., Garde, A.A., Knudsen, C., Krawiec, A.W., Mazur, S., Nygaard, J., Piazolo, S., Thomas, C.W. \& Thrane, K. 2002: Precambrian geology of the northern Nagssug toqidian orogen, West Greenland: mapping in the Kangaatsiaq area. Geology of Greenland Survey Bulletin 191, 13-23.

\footnotetext{
Authors' address

Geological Survey of Denmark and Greenland, Øster Voldgade 10, DK-1350 Copenhagen K, Denmark. E-mail: ast@geus.dk
} 